\title{
Evaluation of green microalgae isolated from central and north coast of Sao Paulo as source of oil
}

\author{
Marcelo Chuei Matsudo ${ }^{\mathrm{a} *\left(\mathbb{0}, \text { Célia Leite Sant }^{\prime} \text { Anna }\right.}{ }^{\mathrm{b}}$, Lina Susana Pérez-Mora ${ }^{\mathrm{c}}$, \\ Roberta Claro da Silvad, João Carlos Monteiro de Carvalho ${ }^{\mathrm{c}(\mathbb{D})}$ \\ a Universidade Federal de Itajubá, Brasil \\ b Instituto de Botânica de São Paulo, Brasil \\ c Universidade de São Paulo, Brasil \\ d North Carolina Agricultural and Technical State University, USA \\ *Autor correspondente (mcmatsudo@unifei.edu.br)
}

\section{N F O}

Keywords
microalgae
biomass
single-cell-oil
fatty acids
lipids

\section{Palavras-chaves}

microalgas

biomassa

single-cell-oil

ácidos graxos

lipídios

\begin{abstract}
A B S T R A C T
Evaluation of green microalgae isolated from central and north coast of Sao Paulo as source of oil.

Microalgae strains, newly isolated from freshwater in mangrove areas of Central and North Coasts of Sao Paulo State (Brazil), were evaluated regarding total protein and lipid content, and fatty acids profile. The biochemical composition was compared with that observed in strains obtained by UTEX Culture Collection (USA). Among seven identified green algae, Monoraphidium contortum (CCMA-UFSCar701) presented the highest lipid content (43.60\%), close to that observed in Botryococcus braunii (UTEX$2441 ; 48.85 \%)$. Protein content in isolated strains varied in the range of 13.90 23.60\%. Finally, the most abundant fatty acids were palmitic acid (C16:0), oleic acid (C18:1), linoleic acid (C18:2), and $\gamma$-linolenic acid (C18:3).Chlorella sp. (CCMA- UFSCar-697) may be highlighted for its high linoleic acid content (29\%). On the other hand, Elakatothrix sp (CCMA- UFSCar-702) and Scenedesmus obliquus (UTEXB2630) presented the highest content of oleic acid (41\% and 43\%, respectively), which is preferable for oils to be used as feedstock for biodiesel.
\end{abstract}

\section{R E S U M O}

Avaliação de microalgas verdes isoladas nas costas central e norte de São Paulo como fonte de óleos. Microalgas de água doce, isoladas em áreas de mangue nas costas central e norte do estado de São Paulo (Brasil), foram avaliadas considerando conteúdo de lipídios, perfil de ácidos graxos e conteúdo de proteínas. Essa composição bioquímica foi comparada com cepas obtidas da Coleção de Culturas da UTEX (EUA). Entre as sete algas verdes identificadas, Monoraphidium contortum (CCMA-UFSCar-701) apresentou o maior conteúdo lipídio (43,60\%), valor próximo ao observado em Botryococcus braunii (UTEX$2441,48,85 \%)$. O conteúdo de proteínas nos isolados variou entre 13,90 e 23,60\%. Os ácidos graxos mais abundantes foram ácido palmítico (C16:0), ácido oleico (C18:1), ácido linoleico (C18:2) e ácido $\gamma$-linolénico (C18:3).Chlorella sp. (CCMA-UFSCar-697) destacou-se por seu alto conteúdo de ácido linoleico (29\%), enquanto Elakatothrix sp (CCMA-UFSCar-702) e Scenedesmus obliquus (UTEX-B2630) apresentaram o maior conteúdo de ácido oleico (41\% e 43\%, respectivamente), sendo que este ácido se destaca como matéria prima para produção de biodiesel. 


\section{INTRODUCTION}

Microalgae may be found in marine environments, freshwater or even in soil (Norton et al., 1996) and they are believed to be responsible for at least $60 \%$ of primary productivity on Earth (Chisti, 2004). Tens of thousands of microalgal species have been classified, and this high diversity may represent a promising source of new bioproducts and applications (Norton et al., 1996; Pulz and Gross, 2004).

Several studies focus on a diversity of applications of microalgal biotechnology in food, cosmetics and pharmaceutical industries, including: food and feed supplements, antioxidative compounds, carotenoids, polyunsaturated fatty acids, vitamins, and immunologically active polysaccharide (Derner et al., 2006; Gouveia et al., 2011; Olaizola, 2003; Pulz and Gross, 2004). More recently, microalgae have been highlighted as valuable alternative and sustainable source of third generation biofuels (Chen et al., 2014; Chisti, 2007).

It is important to note that unicellular photosynthetic organisms are capable of using light energy more efficiently, in comparison with higher plants (Janssen et al., 2003), being considered very efficient for carbon dioxide bio-fixation (Brown and Zeiler, 1993). Moreover, they can be cultivated in controlled conditions, presenting desired and stable composition (Dunstan et al., 1993; Sassano et al., 2010) and favoring industrial/ commercial operations.

This study aimed to evaluate the potential of green microalgae as a source of oil-rich biomass. Seven green algae strains were isolated from freshwater in mangrove areas of Central and North Coast of Sao Paulo State. The lipid content, fatty acids profile, and protein content were compared with that of green microalgae obtained from Culture Collection.

\section{MATERIAL AND METHODS}

\section{Sample collection and isolation}

Using sterile glass bottles, freshwater samples (1 $\sim 1.5 \mathrm{~L}$ ) were collected in different mangrove areas within "Serra do Mar" State Park located in the cities of Cubatão and Ubatuba (Central and North Coast of São Paulo State - Brazil). Geographical coordinates are shown in table 1. Concomitantly with the collection of samples, temperature and $\mathrm{pH}$ ( $\mathrm{pH}$-indicator strips; Merck) were measured.

At the laboratory, microalgae containing water samples were used to inoculate enriched standard culture media: BOLD (UTEX, n.d.), CHU (UTEX, n.d.), Schlosser (Schlösser, 1982), and F/2 (Guillard and Ryther, 1962). When the culture became visually greenish, the isolation took place by combining micropipette method and streaking cell across agar plates (Andersen and Kawachi, 2005), in order to isolate unique species of microalga from the water samples.

\section{Isolates identification}

Isolated strains were observed under Olympus system microscope model BX51 and images were captured with camera Olympus SC30. Microscopic identifications were based on the morphology of the individual cells and colonial characteristics.

\section{Cultivation of isolate strains}

Isolated microalgae strains were cultivated in the BOLD medium. Microalgae were grown in $6 \mathrm{~L}$ Erlenmeyer flasks containing $3 \mathrm{~L}$ of culture medium. Filtered air was continuously injected with the use of air stone diffuser. Room temperature was adjusted to $25{ }^{\circ} \mathrm{C}$, and $30 \mathrm{~W}$ fluorescent lamps were positioned above the flasks for providing light intensity of $60 \mu \mathrm{mol}$ photons.m ${ }^{2} . \mathrm{s}^{-1}$. Initial $\mathrm{pH}$ was adjusted to 7.0 .

Cell growth was indirectly measured by optical density at $550 \mathrm{~nm}$ (Becker, 1994) using a spectrophotometer (Femto 700 Plus), and the cultivation was finished when there was no further daily increase in optical density. Furthermore, four microalgae strains (Chlorophyceae) obtained from The Culture Collection of Algae at the University of Texas at Austin (UTEX) were cultivated in the same conditions: Botryococcus braunii (Utex 2441), Chlorella vulgaris (Utex 2714), Neochloris oleoabundans (Utex 1185), and Scenedesmus obliquus (Utex B2630).

\section{Microalgal biomass evaluation}

At the ended of each cultivation, biomass was recovered by centrifugation, washed twice with distilled water, and dried at $55{ }^{\circ} \mathrm{C}$ for $12 \mathrm{~h}$. Dry biomass was submitted to the determination of total lipids, employing organic solvents (chloroform: methanol 2:1, v/v) in Soxhlet extractor (Olguín et al., 2001; Piorreck et al., 1984). Lipid fraction, recovered with petroleum ether, was submitted to analysis of fatty acids content, after conversion to corresponding methyl esters (Hartman and Lago, 1973). The analysis of fatty acid methyl esters (FAME) was performed in a gas chromatograph (Agilent Model $7890 \mathrm{CX}$ ) in accordance with Rodrigues-Ract and Gioelli (Rodrigues-Ract and Gioielli, 2008) and Perez-Mora et al. (Pérez-Mora et al., 2016). FAME components were identified by comparing their retention time with the standard 37 FAME mix (Supelco).

Furthermore, total protein content in dry biomass was analyzed by the Kjeldahl method, and 
factor 6.25 was adopted to convert from total nitrogen content (AOAC, 1984).

\section{RESULTS AND DISCUSSION}

In table 1 , it is possible to see data from collection sites. $\mathrm{pH}$ values were within 6.5 and 7.0, and temperature values were in the range 25.5 and 30.0. In fact, higher temperature (30.0) observed at Cotia - Pará Park may be attributed to the shallow water (approximately $5.0 \mathrm{~cm}$ ).

Table 1 - Collection sites at Nucleo Itutinga-Piloes (Cb) in the city of Cubatão (S.P.) and Nucleo Picinguaba (P) in the city of Ubatuba (S.P.).

\begin{tabular}{cccc}
\hline Collection site & Temperature & pH & Location \\
\hline $\mathrm{Cb} 1$ & $26.0^{\circ} \mathrm{C}$ & 7.0 & $-23.8955 \mathrm{~S}-46.4621 \mathrm{~W}$ \\
$\mathrm{Cb} 2$ & $26.0^{\circ} \mathrm{C}$ & 7.0 & $-23.8988 \mathrm{~S}-46.4647 \mathrm{~W}$ \\
$\mathrm{Cb} 3$ & $30.0^{\circ} \mathrm{C}$ & 7.0 & $-23.9057 \mathrm{~S}-46.4285 \mathrm{~W}$ \\
$\mathrm{P} 3$ & $25.5^{\circ} \mathrm{C}$ & 6.5 & $-23.3556 \mathrm{~S}-44.8646 \mathrm{~W}$ \\
\hline
\end{tabular}

Cb1: Affluent of Piloes River; Cb2: Piloes River ; Cb3: Cotia-Pará Park; P3: Paciencia River.

In the same day at the laboratory, collected samples were used to inoculate different culture medium, generally used for photosynthetic microorganisms: BOLD (UTEX, n.d.), CHU (UTEX, n.d.), Schlosser (Schlösser, 1982), and F/2 (Guillard and Ryther, 1962). After 2 to 3 weeks, BOLD medium containing flasks showed the most intense green color and these cultures were employed for isolation of 7 microalgae strains.

The identification of isolated strains was performed following the classification system by microscopic identifications based on morphological characteristics. As it is possible to see in table 2, all isolates belong to the Chlorophyceae class.

Table 2 - List of strains isolated from Nucleo Itutinga Pilões $(\mathrm{Cb})$ in the city of Cubatão (S.P.) and Nucleo Picinguaba (P) in the city of Ubatuba (S.P.).

\begin{tabular}{ccc}
\hline Our code & Organism & Accesion number $^{\mathbf{a}}$ \\
\hline CB1a & Chlorella vulgaris & CCMA-UFSCar 698 \\
CB2b & Elakatothrix sp. & CCMA-UFSCar 702 \\
CB3c & Monoraphidium contortum & CCMA-UFSCar 696 \\
CB2c & Chlorella sp. & CCMA-UFSCar 697 \\
CB1Re & Chlorella vulgaris & CCMA-UFSCar 704 \\
P3Fa & Chlorella sp. & CCMA-UFSCar 693 \\
$\mathrm{P} 3 F b$ & Monoraphidium contortum & CCMA-UFSCar 701 \\
\hline
\end{tabular}

a: Culture Collection of Freshwater Microalgae - Federal University of São Carlos.

Figure 1 and 2 shows photomicrographs of isolated microalgal strain from Nucleo Picinguaba (Ubatuba - S.P) and strain from Nucleo ItutingaPilões (Cubatão - S.P.), respectively. They were deposited in the Culture Collection of Freshwater Microalgae of The Federal University of São Carlos (CCMA-UFSCar). Some observed microscopic characteristics are described:

- Chlorella sp. (Beijerinck, 1890). (Figure 1A). Spherical, solitary cells with a single parietal chloroplast. It was also observed that reproduction takes place by autospores (disruption of the mother cell wall).

- Monoraphidium contortum (Komárková-Legnerová, 1969). (Figure 1B). Cells without mucilage and one parietal chloroplast, straight shape to lunate to sigmoid. Smooth cell wall. - with one parietal chloroplast.
- Chlorella vulgaris (Beijerinck, 1890). (Figure 2A). Single cells or colonies, spherical to subspherical, with one parietal chloroplast.

- Elakatothrix.sp. (Wille, 1898). (Figure 2B). Solitary or colonial cells. Random colony shape determined by cell arrangement. Hyaline and thin cell membrane. Fusiform cells with one parietal chloroplast.

- Monoraphidium contortum (Komárková-Legnerová, 1969) (Figure 2C). Cells with lunate form and elongate ends with single parietal chloroplast. Flat cell walls.

- Chlorella sp. (Beijerinck, 1890) (Figure 2D). Spherical to subspherical cells, single or in colonies. One parietal chloroplast.

- Chlorella vulgaris (Beijerinck, 1890) (Figure 2E). Single spherical cells 


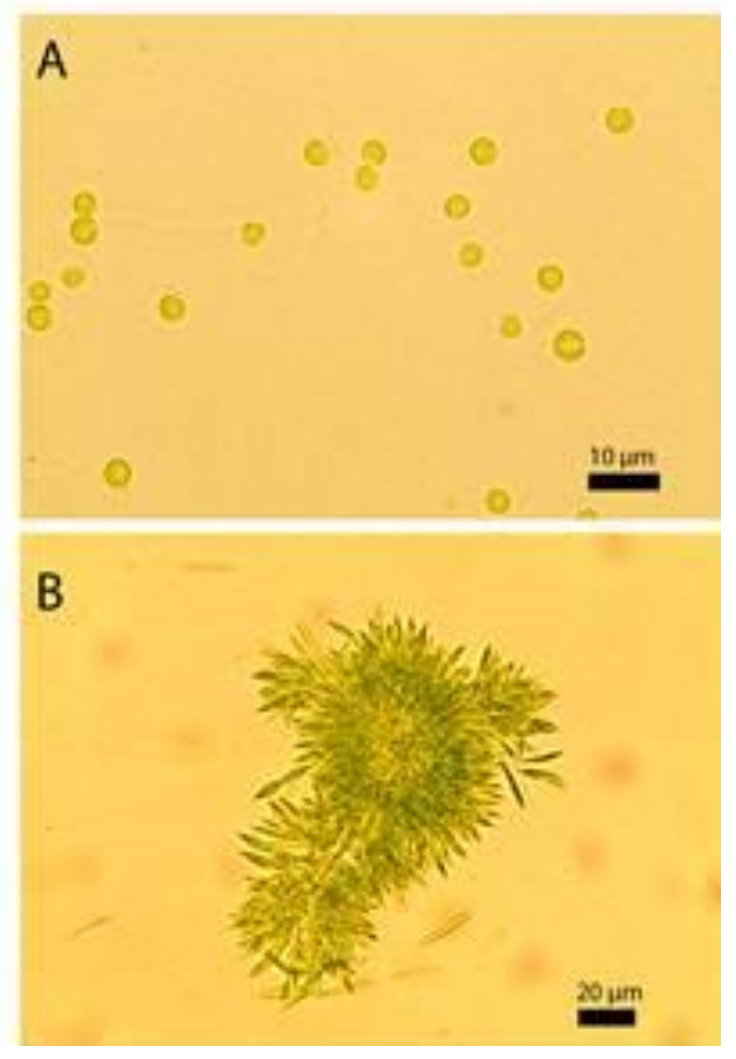

Figure 1 - Photomicrographs of isolated microalgal strain from Nucleo Picinguaba (Ubatuba - S.P.). A: Chlorella sp. (CCMA-UFSCar 693; our code: P3F-a). B: Monoraphidium contortum. (CCMA-UFSCar 701; our code: P3F-b).
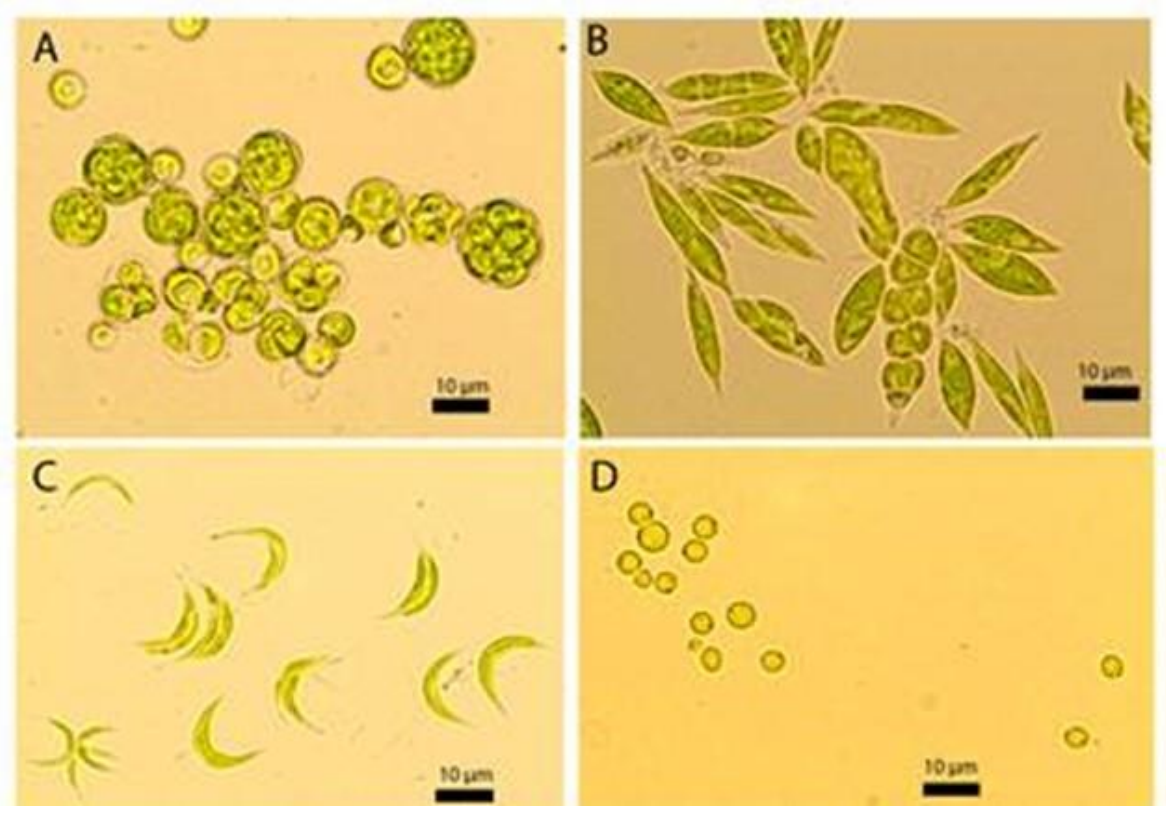

$E$
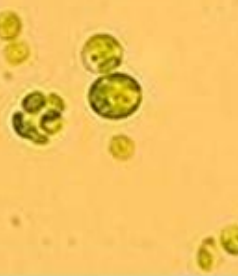

Figure 2 - Photomicrographs of isolated microalgal strain from Nucleo Itutinga-Pilões (Cubatão - S.P.). A: Chlorella vulgaris (CCMA-UFSCar 698; our code: CB1a); B: Elakatothrix sp. (CCMA-UFSCar 702; our code: CB2b); C: Monoraphidium contortum. (CCMA-UFSCar 696; our code: CB3c); D: Chlorella sp. (CCMAUFSCar 697; our code: CB2c); E: Chlorella vulgaris. (CCMA-UFSCar 704; our code: CB1-Re). 
All these isolates and the four microalgae strain obtained from Culture Collection (UTEX) were cultivated in $6 \mathrm{~L}$ Erlenmeyer flasks containing $3 \mathrm{~L}$ of BOLD Basal Medium for obtaining sufficient biomass for biochemical analysis: total protein content, total lipid content, and fatty acids profile.

Table 3 shows results from the analysis of total lipid and total protein content. Total lipid content varied from 18.07 to $43.60 \%$ in isolated strains and from 21.40 to $48.85 \%$ in microalgae strains obtained from Culture Collection (UTEX)

The fatty acid profile of each strain was obtained by analysis of fatty acid methyl esters (FAME) by gas chromatography. The results in table A1 (Annex 1) presented palmitic acid (16:0), oleic acid (18:1n9), linoleic acid (C18:2n6), and $\gamma$-linolenic acid (C18:3n6) as the most abundant fatty acids for these strains.

Table 3 - Total lipid and total protein contents in the biomass of isolated strains and microalgae from Culture Collection (UTEX).

\begin{tabular}{lcc}
\hline \multicolumn{1}{c}{ Strain } & Total Lipid (\%) & Total Protein (\%) \\
\hline CB1-a: Chlorella vulgaris & $25.29 \pm 1.16$ & $23.60 \pm 0.41$ \\
CB2b: Elakatothrix sp. & $30.10 \pm 1.86$ & $13.90 \pm 0.27$ \\
CB2c: Chlorella sp. & $18.07 \pm 0.95$ & $19.31 \pm 0.14$ \\
CB1-Re: Chlorella vulgaris & $27.09 \pm 0.51$ & $16.44 \pm 0.19$ \\
CB3c: Monoraphidium contortum & $34.53 \pm 0.86$ & $20.34 \pm 2.32$ \\
P3Fa: Chlorella sp. & $26.02 \pm 2.88$ & $20.88 \pm 0.37$ \\
P3Fb: Monoraphidium contortum & $43.60 \pm 0.69$ & $14.80 \pm 0.14$ \\
Botryococcus braunii (UTEX 2441) & $48.85 \pm 0.72$ & $14.05 \pm 0.78$ \\
Chlorella vulgaris (UTEX 2714) & $21.59 \pm 2.13$ & $26.23 \pm 2.72$ \\
Neochloris oleoabundans (UTEX 1185) & $21.40 \pm 0.34$ & $29.28 \pm 0.73$ \\
Scenedesmus obliquus (UTEX B2630) & $29.09 \pm 2.31$ & $15.16 \pm 0.72$ \\
\hline
\end{tabular}

The isolated Monoraphidium contortum (CCMA-UFSCar 701) and the purchased Botryococcus braunii (UTEX 2441) presented the highest values of lipid content $(43.60 \%$ and $48.85 \%$, respectively). The lack of nutrients at the end of the cultivation may have contributed to the increase in lipid content, as a result of the well-known phenomenon of triacylglycerol synthesis in response to stress condition (Liu and Benning, 2013). However, further studies have to be performed for a specific strain, since lipid metabolism seems not to be uniform in the algal realm (Liu and Benning, 2013).

Mahmoud et al. (Mahmoud et al., 2015) evaluated microalgae strains isolated in different locations in Egypt. Among fifteen isolates, they highlighted Chlorella vulgaris, Scenedesmus quadricauda and Trachelomonas oblonga as the most suitable candidates for oil production, with $37 \%$, $34 \%$ and $29 \%$ of lipid (w/w), respectively.

Several studies have been done, not only submitting microalgae to stress conditions but also with genetic approaches. For example, increases in lipid accumulation were observed when the starch synthesis pathway was blocked in mutants of Chlamydomonas (Li et al., 2010) and Chlorella (Ramazanov and Ramazanov, 2006).

After the extraction of oil, defatted biomass may contain hydrophilic compounds with commercial interests, such as sugars and proteins (Bellou et al., 2014). Microalgal proteins may be used in pharmaceutical products, cosmetics or mainly for food and feed supplements (Derner et al., 2006; Pulz and Gross, 2004). In the present study, total protein content varied in the range $13.90 \sim 23.60 \%$ in biomass of isolated microalgae strains and $14.05 \sim 29.28 \%$ in biomass of microalgae obtained from Culture Collection (UTEX).

The values of protein content obtained in this study were much lower than the values observed among the data presented by Barka \& Blecker (Barka and Blecker, 2016), where some species of Chlorophyceae strains present protein content higher than $40 \%$ or even higher than $50 \%$. However, to produce Single Cell Protein, for example, it would worth it to evaluate the physico-chemical condition for increasing the biosynthesis of these biomolecules, mainly light intensity and nitrogen content. In this context, there are several studies showing the possibility of increasing protein content in Arthrospira platensis in different types of photobioreactor by fed-batch process (Cruz-Martínez et al., 2015); repeated fed-batch (Matsudo et al., 2009) or continuous process (Avila-Leon et al., 2012; Matsudo et al., 2012)

Concerning fatty acids profile, linoleic and $\gamma$-linolenic acid, commonly known as $\omega-6$ fatty acids, are precursors of arachidonic acid, which is important in the synthesis of eicosanoids in human body (Verlengia and Lima, 2002). These eicosanoids may play a role as mediators in processes associated to inflammation, immune system modulation, and platelet aggregation (Kus et al., 2011). 
Isolated Chlorella sp. (CCMA-UFSCar 697) showed the highest content of linoleic acid (29\%) and, among the strains from UTEX culture collection, Neochloris abundans (UTEX 1185) presented the highest content of this fatty acid (36\%) (Table A1 - Annex 1).

In the case of $\gamma$-linolenic acid, Chlorella $s p$. (CCMA-UFSCar 697), Chlorella vulgaris (CCMA-UFSCar 698), and Neochloris oleoabundans (UTEX 1185) presented the highest values (23, 22, and 19\%, respectively) (Table A1 - Annex 1). It is important to note that, the consumption of this fatty acid may be useful in the case of deficiency in delta-6-dessaturase, responsible for its ordinary synthesis in the human body (Horrobin, 1992). In this sense, it is worth it using one of these strains for further studies aiming to increase unsaturated fatty acids. For example, Ronda \& Lele (Ronda and Lele, 2008) observed that increasing light intensity and decreasing temperature have a positive effect on the content of $\gamma$-linolenic acid.

Palmitic acid was above $20 \%$ in all the evaluated strains, but the highest contents were observed in that from UTEX culture collection, Chlorella vulgaris (46\%) and Scenedesmus obliquus (34\%) (Table A1 - Annex 1). The abundance of this fatty acid was also found by Molino et al. (Molino et al., 2018) in the green algae Chlorella vulgaris and $\mathrm{Du}$ naliella salina.

The most abundant FAME, presented in the strains evaluated in the present study, are within the most common fatty esters in biodiesel, in accordance with Knothe (Knothe, 2008). Moreover, Elakatothrix sp (CCMA-UFSCar 702) and Scenedesmus obliquus (UTEX B2630) presented the highest content of oleic acid ( $41 \%$ and $43 \%$, respectively), which is preferable for oils to be used as feedstock for biodiesel (Knothe, 2008; Mahmoud et al., 2015).

\section{CONCLUSION}

In this study, 7 green microalgae strains, isolated from freshwater in mangrove areas of Central and North Coasts of Sao Paulo State (Brazil), were evaluated regarding total lipid content, fatty acids profile, and total protein content. 4 strains obtained by UTEX Culture Collection (USA) were also evaluated for comparisons. Monoraphidium contortum (CCMA-UFSCar 701) presented the highest lipid content (43.60\%), close to the lipid content observed in Botryococcus braunii (UTEX 2441; 48.85\%). Protein content in isolated strains varied in the range of $13.90 \sim 23.60 \%$. The most abundant fatty acids were palmitic acid (C16:0), oleic acid (C18:1), linoleic acid (C18:2), and $\gamma$ linolenic acid (C18:3). Chlorella sp. (CCMA-
UFSCar 697) may be highlithted for its high linoleic acid content (29\%). On the other hand, Elakatothrix sp (CCMA- UFSCar 702) and Scenedesmus obliquus (UTEX B2630) presented the highest content of oleic acid $(41 \%$ and $43 \%$, respectively), which is preferable for oils to be used as feedstock for biodiesel.

\section{ACKNOWLEDGEMENTS}

The authors thank CAPES (Coordenação de Aperfeiçoamento de Pessoal de Nível Superior Brasil - Finance Code 001) and Fapesp (Fundação de Amparo à Pesquisa do Estado de São Paulo) for grant 10/51503-4. We also thank Parque Estadual Serra do Mar - Núcleo Itutinga Pilões (Cubatão S.P.) and Núcleo Picinguaba (Ubatuba - S.P.).

\section{REFERENCES}

Andersen RA, Kawachi M. Traditional micoalgae isolation techniques. In: Andersen RA (Ed.) Algal culturing techniques. Esevier Academic Press, pp.83-100, 2005

AOAC. Official Methods of Analysis of the Association of Official Analytical Chemists, 14th ed. Arlington: American Public Health Association, 1141p. 1984.

Avila-Leon I, Matsudo MC, Sato S, Carvalho JCM. Arthrospira platensis biomass with high protein content cultivated in continuous process using urea as nitrogen source. Journal of Applied Microbiology, v. 112, p. 1086-1094, 2012. https://doi.org/10.1111/j.1365-2672.2012.05303.x

Barka A, Blecker C. Microalgae as a potential source of single-cell proteins. A review. Biotechnology, Agronomy, Society and Envionment, v. 20, p. 427-436, 2016. DOI: 10.25518/1780-4507.13132

Becker EW. Microalgae - Biotechnology and Microbiology. New york: Cambridge University Press, 293p. 1994.

Beijerinck MW. Kulturversuche mit Zoochlorellen, Lichenengonidien und anderen nie-deren Algen. Bot Zeitung, v. 47 , p. $725-788,1980$.

Bellou S, Baeshen MN, Elazzazy AM, Aggeli D, Saygh F, Aggelis G. Microalgal lipids biochemistry and biotechnological perspectives. Biotechnology Advances, v.32, p. 1476-1493, 2014. https://doi.org/10.1016/j.biotechadv.2014.10.003

Brown ML, Zeiler KG. Aquatic biomass and carbon dioxide trapping. Energy Conversion and Management, v.34, p. 1005-1013, 1993. https://doi.org/10.1016/01968904(93)90048-F

Chen X, He G, Deng Z, Wang N, Jiang W, Chen S. Screening of Microalgae for Biodiesel Feedstock. Advances in Microbiology,v.4, p.365-376, 2014. https://doi.org/10.4236/aim.2014.47044

Chisti Y. Biodiesel from microalgae. Biotechnology Advances, v.25, p.294-306, 2007. https://doi.org/10.1016/j.biotechadv.2007.02.001 
Chisti Y. Microalgae: our marine forests. In: Richmond A. (Ed.) Handbook of microalgal culture: biotechnology and applied phycology. Oxford: Blackwell Science. 566p. 2004.

Cruz-Martínez LC, Jesus CKC, Matsudo MC, Danesi EDG, Sato S, Carvalho JCM. Growth and composition of Arthrospira (Spirulina) platensis in a tubular photobioreactor using ammonium nitrate as the nitrogen source in a fed-batch process. Brazilian Journal of Chemical Engineering, v.32, p.347-356, 2015. https://doi.org/10.1590/01046632.20150322s00003062

Derner RB, Ohse S, Villela M, Villela M, Carvalho SM, Fett R. Microalgae, products and applications. Ciência Rural, v.36, p.1959-1967, 2006. https://doi.org/10.1590/S010384782006000600050

Dunstan GA, Volkman JK, Barrett SM, Garland CD. Changes in the lipid composition and maximisation of the polyunsaturated fatty acid content of three microalgae grown in mass culture. Journal of Applied Phycology, v.5, p.71-83, 1993. https://doi.org/10.1007/BF02182424

Gouveia L, Marques AE, Sousa JM, Moura P, Bandarra N. Microalgae - source of natural bioactive molecules as functional ingredients. Food Science and Technology Bulletin, v.7, p. 21-37, 2011. https://doi.org/10.1616/14762137.15884

Guillard RRL, Ryther JH. Studies of marine planktonic diatoms. Canadian Journal of Microbiology, v.8, p.229-239, 1962. https://doi.org/10.1139/m62-029

Hartman L, Lago RC. Rapid preparation of fatty acid methyl esters from lipids. Laboratory Practices, v.22, p.475-477, 1973.

Horrobin DF. Nutritional and medical importance of gammalinolenic acid. Progress in Lipid Research, v.31, p.163-194, 1992. https://doi.org/10.1016/0163-7827(92)90008-7

Janssen M, Tramper J, Mur LR, Wijffels RH. Enclosed outdoor photobioreactors: Light regime, photosynthetic efficiency, scale-up, and future prospects. Biotechnology and Bioengineering, v.81, p.193-210, 2003.

https://doi.org/10.1002/bit.10468

Knothe G. "Designer" Biodiesel: optimizing fatty ester composition to improve fuel properties. Energy Fuels, v.22, p.1358-1364, 2008. https://doi.org/10.1021/ef700639e

Komárková-Legnerová J. The systematics and ontogenesis of the genera Ankistrodesmus Corda and Monoraphidium gen. nov. Academia, 70p. 1969.

Kus MMM, Silva SA, Aued-Pimentel S, Mancini-Filho J. Nutrition facts of infant formulas sold in São Paulo state: assessment of fat and fatty acid contents. Revista de Nutrição, v.24, p.209-218, 2011.

https://doi.org/10.1590/S1415-52732011000200002

Li Y, Han D, Hu G, Sommerfeld M, Hu Q. Inhibition of Starch Synthesis Results in Overproduction of Lipids in Chlamydomonas reinhardtii. Biotechnology and Bioengineering, v.107, p.258-268, 2010. https://doi.org/10.1177/0969733010361439

Liu B, Benning C. Lipid metabolism in microalgae distinguishes itself. Current Opinion in Biotechnology, v.24, p.300-309, 2013. https://doi.org/10.1016/j.copbio.2012.08.008
Mahmoud EA, Farahat LA, Abdel Aziz ZK, Fatthallah NA, El Din RAS. Evaluation of the potential for some isolated microalgae to produce biodiesel. Egyptian Journal of Petroleum, v.24, p.97-101, 2015. https://doi.org/10.1016/j.ejpe.2015.02.010

Matsudo M, Bezerra R, Sato S, Perego P, Converti A, Carvalho JCM. Repeated fed-batch cultivation of Arthrospira (Spirulina) platensis using urea as nitrogen source. Biochemical Engineering Journal, v.43, p.52-57, 2009. https://doi.org/10.1016/j.bej.2008.08.009

Matsudo MC, Bezerra RP, Sato S, Converti A, Carvalho JCM. Photosynthetic efficiency and $\mathrm{CO} 2$ assimilation rate of Arthrospira (Spirulina) platensis continuously cultivated in tubular photobioreactor. Biotechnology Journal, v.7, p.1412-1417, 2012. https://doi.org/10.1002/biot.201200177

Molino A, Iovine A, Casella P, Mehariya S, Chianese S, Cerbone A, Rimauro J, Musmarra D. Microalgae characterization for consolidated and new application in human food, animal feed and nutraceuticals. International Journal of Environmental Research and Public Health, v.15, p.1-21, 2018. https://doi.org/10.3390/ijerph15112436

Norton TA, Melkonian M, Andersen RA. algal biodiversity. Phycologia, v.35, p.308-326, 1996. https://doi.org/10.2216/i0031-8884-35-4-308.1

Olaizola M. Commercial development of microalgal biotechnology: From the test tube to the marketplace. Biomolecular Engineering, v. 20, p. 459-466, 2003. https://doi.org/10.1016/S1389-0344(03)00076-5

Olguín E, Galicia S, Angulo O, Hernández E. The effect of low light flux and nitrogen deficiency on the chemical composition of Spirulina sp. growth on pig waste. Bioresourse Technology, v.77, p.19-24, 2001. https://doi.org/10.1016/S0960-8524(00)00142-5

Pérez-Mora LS, Matsudo MC, Cezare-Gomes EA, Carvalho JCM, An investigation into producing Botryococcus braunii in a tubular photobioreactor. Journal of Chemical Technology and Biotechnology, v.91, p.3053-3060, 2016. https://doi.org/10.1002/jctb.4934

Piorreck M, Baasch K, Pohl P. Biomass production, total protein, chlorophylls, lipids and fatty acids of freshwater green and blue-green algae under different nitrogen regimes. Phytochemistry, v.23, p.207-216, 1984.

Pulz O, Gross W. Valuable products from biotechnology of microalgae. Appl Microbiol Biotechnol, v.65, p.635-648, 2004. https://doi.org/10.1007/s00253-004-1647-x

Rodrigues-Ract JNR, Gioielli LA. Modified lipids obtained from milk fat, sunflower oil, and phytosterols esters for application in spreads. Quim Nova, v.31, p.1960-1965, 2008. https://doi.org/http://dx.doi.org/10.1590/S010040422008000800008

Ramazanov A, Ramazanov Z. Isolation and characterization of a starchless mutant of Chlorella pyrenoidosa STL-PI with a high growth rate, and high protein and polyunsaturated fatty acid content. Phycological Research, v.54, p.255-259, 2006. https://doi.org/10.1111/j.14401835.2006.00416.x

Ronda SR, Lele SS. Culture conditions stimulating high $\gamma$-linolenic acid accumulation by Spirulina platensis. Brazilian 
Journal of Microbiology, v.39, p.693-697, 2008.

https://doi.org/10.1590/S1517-83822008000400018

Sassano CEN, Gioielli LA, Ferreira LS, Rodrigues MS, Sato S, Converti A, Carvalho JCM. Evaluation of the composition of continuously-cultivated Arthrospira (Spirulina) platensis using ammonium chloride as nitrogen source. $\mathrm{Bi}$ omass and Bioenergy, v.34, p.1732-1738, 2010. https://doi.org/10.1016/j.biombioe.2010.07.002

Schlösser UG. Sammlung von Algenkulturen. Berichte der Deutschen Botanischen Gesellschaft, v.95, p.181-276, 1982. https://doi.org/10.1111/j.1438-8677.1982.tb02862.x

UTEX. The Culture Collection of Algae at the University of Texas at Austin. http://www.sbs.utexas.edu/utex/. Accessed 3 Sep 2011

Verlengia R, Lima TM. Síntese de Ácidos Graxos. In: Curi R, Pompeia C, Miyasaka CK, Procópio J (Eds) Entendendo a gordura: os ácidos graxos. São Paulo: Manole. pp.121134, 2002.

Wille N. Beschreibung einiger Planktonalgen aus norwegischen süsswasserseen. Biologisches Centralblatt, v.18, p. 302, 1898 . 


\section{Annex 1}

Table A1 - Fatty acids profiles found in the isolated species and microalgae from Culture Collection (UTEX)

\begin{tabular}{|c|c|c|c|c|c|c|c|c|c|c|c|}
\hline $\begin{array}{c}\text { Fatty acid } \\
\qquad(\%)^{\mathrm{a}}\end{array}$ & $\begin{array}{c}\text { Chlorella } \\
\text { vulgaris } \\
\text { CB1a }\end{array}$ & $\begin{array}{c}\text { Elaka- } \\
\text { tothrix sp. } \\
\text { CB2b }\end{array}$ & $\begin{array}{c}\text { Chlorella } \\
\text { sp. } \\
\text { CB2c }\end{array}$ & $\begin{array}{c}\text { Chlorella } \\
\text { vulgaris } \\
\text { CB1-Re }\end{array}$ & $\begin{array}{c}\text { Monoraphid- } \\
\text { ium contortum } \\
\text { CB3-c }\end{array}$ & $\begin{array}{c}\text { Chlorella } \\
\text { sp. } \\
\text { P3Fa }\end{array}$ & $\begin{array}{c}\text { Monoraphid- } \\
\text { ium contortum } \\
\text { P3Fb }\end{array}$ & $\begin{array}{c}\text { Botryococcus } \\
\text { braunii } \\
\text { UTEX 2441 }\end{array}$ & $\begin{array}{c}\text { Chlorella } \\
\text { vulgaris } \\
\text { UTEX 2714 }\end{array}$ & $\begin{array}{c}\text { Neochloris } \\
\text { oleoabun- } \\
\text { dans } \\
\text { UTEX 1185 }\end{array}$ & $\begin{array}{c}\text { Scenedesmus } \\
\text { obliquus } \\
\text { UTEX B2630 }\end{array}$ \\
\hline C12:0 & - & - & - & - & - & - & 3.43 & - & - & - & - \\
\hline C16:0 & 22.57 & 21.61 & 21.19 & 23.06 & 25.57 & 27.48 & 22.43 & 29.72 & 46.92 & 21.72 & 34.92 \\
\hline N.I. ${ }^{\mathrm{b}}$ & - & - & 9.71 & - & 5.23 & - & - & - & - & - & - \\
\hline C16:1 & - & - & - & 2.69 & - & 4.09 & - & - & 4.01 & 2.60 & 3.20 \\
\hline N.I. ${ }^{b}$ & 8.42 & - & - & - & - & 4.57 & 5.40 & - & - & - & - \\
\hline C17:0 & & 3.79 & - & - & 3.88 & - & 5.88 & - & - & - & - \\
\hline $\mathrm{C} 17: 1$ & - & - & 7.37 & 3.12 & - & 6.66 & - & - & 4.08 & 10.31 & 1.44 \\
\hline N.I. ${ }^{b}$ & - & - & - & 6.60 & - & - & - & - & - & - & - \\
\hline C18:0 & - & - & - & 2.95 & - & - & - & 18.29 & 5.32 & - & 3.28 \\
\hline $\mathrm{C} 18: \ln 9$ & 36.69 & 41.67 & 5.73 & 35.40 & 33.28 & 23.48 & 31.39 & 33.37 & 14.87 & 9.22 & 43.68 \\
\hline C18:2n6 & 9.82 & 14.10 & 29.40 & 4.95 & 21.75 & 21.12 & 11.07 & 12.74 & 17.52 & 36.28 & 9.55 \\
\hline C18:3n6 & 22.51 & 14.59 & 23.78 & 21.21 & 10.19 & 12.61 & 13.09 & 5.85 & 7.31 & 19.89 & 3.96 \\
\hline N.I. ${ }^{b}$ & - & 4.24 & - & - & - & - & 4.32 & - & - & - & - \\
\hline C20:3n6 & - & - & 2.85 & 2.32 & - & - & 3.00 & - & - & - & - \\
\hline
\end{tabular}

a Percentage of fatty acids relative to the total content (weight/weight).

${ }^{\mathrm{b}}$ Unidentified compound. Absent in 37 MIX patterns.

C12:0 lauric acid; C16:0 palmitic acid; C16:1 palmitoleic acid; C17:0 heptadecanoic acid; C17:1 cis-10-heptadecenoic acid; C18:0 stearic acid; C18:1n9 oleic acid; C18:2n6 linoleic acid; $\mathrm{C} 18: 3 \mathrm{n} 6 \gamma$-linolenic acid; $\mathrm{C} 20: 3 \mathrm{n} 6$ eicosatrienoic acid.

- : Not detected 